\title{
In vitro release of diclofenac diethylamine from gels: evaluation of generic semisolid drug products in Brazil
}

\author{
Karin Goebel*, Mayumi Eliza Otsuka Sato, Dayse Fernanda de Souza, Fábio Seigi Murakami, \\ Itamar Francisco Andreazza
}

Pharmacy Department, Federal University of Paraná

\begin{abstract}
In order for the pharmacological action of a topical dermal drug product to occur, the drug must first be released from the vehicle to be available to penetrate the skin layers and reach the site of action. Drug release is mainly dependent on the characteristics of the formulation. Currently, to register a generic or a similar drug product in Brazil performance testing of topical drug products for local action is not required. In this context, this aim of this study was to evaluate the in vitro release of commercial diclofenac diethylamine gel products available on the Brazilian pharmaceutical market, using the vertical diffusion cell method. Factors which may influence the test, such as the type of membrane used, and the effect of the formulation characteristics on the diffusion rate were evaluated. Brazilian legislation currently allows generic drug products to contain excipients other than the reference drug, which may affect the drug release from the vehicle. Only one of the four generic drug products tested could be considered equivalent to the reference Cataflam Emulgel ${ }^{\circledR}$. The cellulose acetate and polyethersulfone membranes tested were found to be interchangeable in the in vitro release studies carried out on this product.
\end{abstract}

Uniterms: In vitro release test. Diclofenac diethylamine/gel. Synthetic membranes. Generic semisolid drug products.

Para exercer ação farmacológica, medicamentos tópicos de aplicação cutânea precisam, primeiramente, liberar o fármaco do veículo, para que desta forma ele se torne disponível para penetração nas camadas da pele, até atingir seu local de ação. A liberação do fármaco do veículo depende principalmente das características da formulação. Até a presente data, para registrar um medicamento genérico ou similar no Brasil não se exigem testes de desempenho para produtos tópicos de ação local. O presente trabalho teve como objetivo avaliar a liberação in vitro de especialidades farmacêuticas de diclofenaco dietilamônio gel do mercado farmacêutico brasileiro, usando o sistema de célula de difusão vertical. Avaliaram-se fatores que influenciam o teste como o tipo de membrana usada nos ensaios de liberação e características da formulação que impactam a velocidade de difusão. A legislação vigente no País permite que medicamentos genéricos contenham excipientes diferentes do medicamento referência. Esta diferença afetou a liberação do fármaco do veículo. Dos quatro medicamentos genéricos testados apenas um seria considerado equivalente ao medicamento referência Cataflam Emulgel ${ }^{\circledR}$. As membranas de acetato de celulose e polietersulfona testadas apresentaram-se intercambiáveis nos estudos de liberação desse produto.

Unitermos: Teste de liberação in vitro. Diclofenaco dietilamônio/gel. Membranas sintéticas. Medicamentos genéricos semissólidos.

\footnotetext{
*Correspondence: K. Goebel. Departamento de Farmácia, Divisão de Ciências da Saúde, Universidade Federal do Paraná. Av. Pref. Lothário Meissner, 632 - Jardim Botânico - 80210-170 - Curitiba - PR, Brasil. E-mail: kargoebel@yahoo.com.br
} 


\section{INTRODUCTION}

In vitro performance tests for solids, such as dissolution tests, have been extensively used as a tool in the development of drug formulations, in quality control procedures to ensure lot-to-lot uniformity, to monitor changes in the process and formula and to predict the in vivo performance of the product. A new test to evaluate the performance of semisolid products with the same aims as the dissolution test has been the subject of extensive discussion (Shah, 2005).

Currently, the performance testing system employing the vertical diffusion cell (VDC) is commonly applied to semisolid products, specifically creams, ointments and gels, and also to lotions. This procedure quantifies the release of the active component from the formulation, which diffuses through a membrane into a receptor solution (Ueda et al., 2009).

Generic drugs in semisolid form are launched in large numbers annually onto the Brazilian market and, as yet, there is no specific legislation regulating the performance testing of these products. In Brazil, the current legislation for the registration of generic and similar topical skin products without systemic absorption allows that bioequivalence is replaced by pharmaceutical equivalence, provided that the drug concentration is the same as the reference and excipients with the same function are present in compatible concentrations (Brasil, 2003).

In 2009, the United States Pharmacopeia Forum suggested the use of VDCs with synthetic membranes to test the performance of topical products (Ueda et al., 2009). In the same year, with the publication of the RDC n. 48, ANVISA (the regulatory agency in Brazil), the Brazilian government required that an in vitro permeation study be carried out to compare semisolid formulations before and after post-approval changes (Brasil, 2009). However, the products are not compared with the reference drug at the time of registration. Despite this requirement, there is no official guidance for the Brazilian pharmaceutical industry regarding how to perform the test or providing specifications.

The aim of this study was to evaluate the situation regarding semisolid pharmaceutical forms of generic drugs available on the Brazilian market. In addition, since there is no standardization of the test parameters, such as the type of artificial membrane to be used, the development of release test methodologies is also discussed based on formulations of diclofenac diethylamine (DDA) gel, a widely used anti-inflammatory topical drug, studied as a model formula/drug.

\section{MATERIAL AND METHODS}

\section{Products}

The topical dermatological dosage forms were purchased on the Brazilian market, these being the reference Cataflam Emulgel ${ }^{\circledR} 11.6 \mathrm{mg} / \mathrm{g}$ (manufactured by Novartis Pharma Produktions GmbH, Germany, imported by Novartis Biociências S.A., Brazil) and four generic drug products produced by different manufacturers and referred to herein as generic $\mathrm{A}$, generic $\mathrm{B}$, generic $\mathrm{C}$ and generic D.

\section{Reagents}

Two types of hydrophilic synthetic membranes, with $0.45 \mu \mathrm{m}$ pore size, were used in this study: polyethersulfone (47 mm diameter, thickness $\geq 130$ and $\leq 155 \mu \mathrm{m}$, Millipore ${ }^{\circledR}$, USA) and cellulose acetate ( $47 \mathrm{~mm}$ diameter, $120 \mu \mathrm{m}$ thickness, Sartorius ${ }^{\circledR}$, Germany). Reagents included a diclofenac sodium standard (99.08\%). All other reagents were of analytical grade and used as received.

\section{In vitro release test}

The in vitro release tests were performed using six vertical diffusion cells (Permegear ${ }^{\mathbb{R}}$ ) per formulation. The diffusional area of the cell was $1.75 \mathrm{~cm}^{2}$ and the receptor compartment had a capacity of approximately $10.5 \mathrm{~mL}$. The membranes were cut to a diameter of $25 \mathrm{~mm}$ and saturated for 30 minutes in receptor medium (phosphate buffer $\mathrm{pH}$ 7.4) before starting the experiment. The cell was filled with degassed receptor medium and the membrane was placed in the top of the receptor compartment and checked for air bubbles. An aliquot of the sample was measured with the aid of a syringe and then placed in the cavity of a dosage wafer (donor compartment), on top of the membrane. The amount applied was around $300 \mathrm{mg}$ of gel, equivalent to $3.48 \mathrm{mg}$ of DDA. With a spatula, the gel was spread uniformly filling the donor compartment. A glass disk was carefully placed on the sample to occlude it, and an aligner cap was then used to centralize the assembly, which was held together by a clamp. The receptor medium was maintained at $32 \pm 1{ }^{\circ} \mathrm{C}$ under constant stirring. To characterize the drug release, $400 \mu \mathrm{L}$ samples were collected after $0.5,1,1.5,2,3,4$, 5 and $6 \mathrm{~h}$. In the case of the reference drug product and generic A samples were also collected after 0.25 hours. After sampling, the volume collected was replaced with fresh receptor medium. The amount of DDA was assayed by chromatographic analysis as described below. 


\section{DDA assay of release test samples}

The DDA assay of the release test samples was performed by high performance liquid chromatography (HPLC) according to a method previously described in the literature (Silva et al., 2009), except that the injection volume of $30 \mu \mathrm{L}$ was reduced to $20 \mu \mathrm{L}$. To verify that the method is suitable for this purpose the linearity, precision and specificity (analyzing the peak purity of the sample chromatograms) were evaluated.

\section{Statistical comparison of the in vitro release data}

The statistical test used to compare the in vitro release rates (fluxes) is a non-parametric statistical method, based on a standard confidence interval (CI) procedure. This test is related to the Wilcoxon Rank Sum/Mann-Whitney rank test, applied to the data for the log of the slope (release rate). For the release rate of the generic $(\mathrm{G})$ run to be within the $90 \% \mathrm{CI}$ in relation to the reference $(R)$ test run, the values for the $G / R$ ratio should lie within the limits of $75 \%$ - 133\% (FDA, 1997; Shah et al., 2003).

\section{Assay of products}

The quantitative determination of DDA in the drug products was performed by HPLC using the method described in the British Pharmacopoeia (2008).

\section{RESULTS AND DISCUSSION}

The in vitro drug release profiles for the release of DDA from the products, using a polyethersulfone membrane, are summarized in Figure 1.

The values for the relative standard deviation (RSD) of the in vitro release from the six cells in each experiment were less than $10 \%$ for all time intervals, indicating the good precision of the method. The correlation coefficient (r) of 0.9996 obtained from the linear regression of the data verified that the method is linear in the concentration range investigated in this study (10 - $300 \mu \mathrm{g} . \mathrm{mL}^{-1}$ of sodium diclofenac). The statistical calculation of similarity between the chromatogram peaks of the standard and the samples resulted in a minimum of $99.2 \%$ purity. These results showed that the excipients do not coeluted with the drug, confirming the specificity of the method.

All of the products had satisfactory contents, in accordance with the limits set by the British Pharmacopoeia of $95-105 \%$.

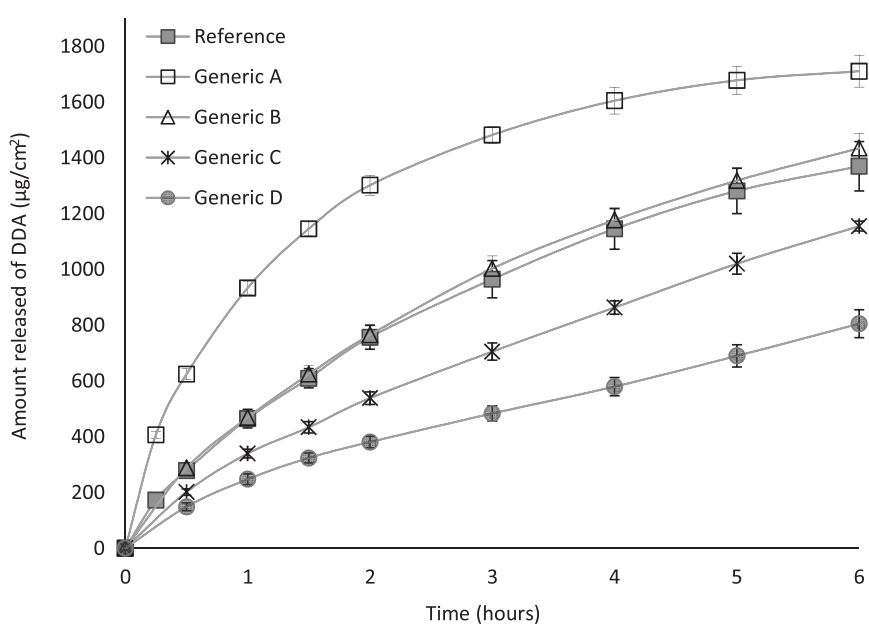

FIGURE 1 - In vitro release of DDA using a polyethersulfone membrane $(n=6)$. Error bars represent the standard deviation (SD).

\section{Calculation of the release rate (flux)}

Guy and Hadgraft (1990), based on a study published by Higuchi (1962), proposed that the processing of data obtained from in vitro release studies should include the adoption of a function based on the square root of time (Figure 2). According to the authors, this procedure is necessary for the linearization of the data and the use of more points on the profile (Higuchi, 1962; Guy, Hadgraft, 1990; Bemvindo, 2006). The representation of the amount released per unit area $\left(\mu \mathrm{g} / \mathrm{cm}^{2}\right)$ as a function of the square root of time allows the drug release rate for a semisolid product to be obtained from the straight line slope (FDA, 1997; Toscano et al., 2001; Ueda et al., 2009).

According to Higuchi (1962), there is a linear relationship between the amount of drug released/diffused and $\sqrt{t}$ when the diffusion through this semisolid matrix is the limiting step of the process and in these circumstances no other parameter (e.g. receptor medium, membrane) has a significant effect.

Also, this relationship has proved to be valid and linear for topical formulations where the percentage of drug released is less than approximately $30 \%$ of the amount applied in the donor compartment, forming the matrix, for an infinite drug dosage. Thus, the diffusion coefficient is not concentration-dependent (Higuchi, 1962; Guy, Hadgraft, 1990; Toscano et al., 1997; Shah, 2005).

Additionally, the concentration in the receptor compartment should not reach $>10 \%$ of the concentration limit of solubility of the drug used in the receptor phase (Toscano et al., 1997). In the case of DDA, reports in the literature indicate that it is very soluble in phosphate buffer $\mathrm{pH} 7.4$, with solubility greater than $6.0 \mathrm{mg} \cdot \mathrm{mL}^{-1}$ (Silva 
et al., 2009). The highest concentration in the receptor medium reached in this study did not exceed $0.3 \mathrm{mg} \cdot \mathrm{mL}^{-1}$, maintaining sink conditions during the analysis.

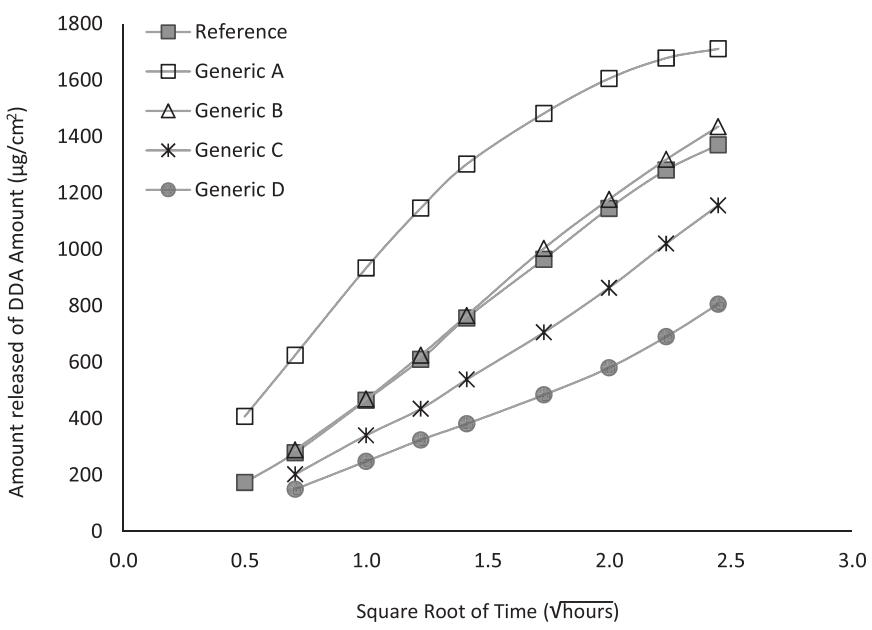

FIGURE 2 - In vitro release of DDA as a function of $\sqrt{t}$, using all points, employing the polyethersulfone membrane $(n=6)$.

\section{Selection of data points to calculate the release rate}

Zatz and Segers (1998) discuss the selection of data points to calculate the in vitro release rate, and state that there is a time window during which the experiments should be performed. Data should be collected when the influence of the membrane and its associated stagnant layer are no longer present but before excessive drug depletion from semisolid occurs.

On this basis, the DDA flux was calculated by linear regression and corresponds to the slope of the first five data points obtained a between 0.5 to $3 \mathrm{~h}$. It is assumed that by
$0.5 \mathrm{~h}$ the diffusion equilibrium would have been reached and after 3 hours the percentage of drug released will not characterize a dose depletion sufficient to influence the release rate, which was confirmed by the linearity of the straight lines.

For the generic A sample the flux was calculated from 0.25 to $2 \mathrm{~h}$ and the reference flux was calculated from 0.5 to $3 \mathrm{~h}$ and 0.25 to $2 \mathrm{~h}$. The reason for this difference in sampling times is that when performing the initial tests the sampling points were designed based on the reference drug product as the parameter, which released around $48 \%$ of the initial drug content of the semisolid within 3 hours (Table I) and the straight line formed by the amount released as a function of square root of time showed good linearity $(\mathrm{r}=0.9995)$.

The release observed for the generic A sample was much faster than in the case of the other generic samples. Within $3 \mathrm{~h}$, generic A had already released $75 \%$ of the drug (Table I), forming an undesired curve with values higher than the square root of time (Figure 2), as previously shown by Zatz and Segers, caused by excessive depletion of DDA in the sample. According to the authors, this is to be expected when the release exceeds approximately 35$45 \%$ of the initial drug content of the semisolid. At this point the basic assumption of the equation that supports the linear relationship between the amount of drug released and the square root of time is no longer valid.

Thus, for generic A, it is necessary to include another sampling point at the beginning of the experiment and neglect the data obtained at $3 \mathrm{~h}$. To compare this product with the reference using the same points, both samples were reanalyzed and subsequently compared with the $0.25 \mathrm{~h}$ sampling point data.

A good linearity for the selected points (Figure 3)

TABLE I - Percentage of initial DDA content released from the semisolid as a function of time using a polyethersulfone membrane

\begin{tabular}{ccccccc}
\hline \multirow{2}{*}{$\begin{array}{c}\text { Time } \\
\text { (hours) }\end{array}$} & $\begin{array}{c}\text { Time } \\
(\sqrt{\text { hours }})\end{array}$ & Reference & Generic A & Generic B & Generic C & Generic D \\
\hline $\mathbf{0 . 2 5}$ & $\mathbf{0 . 5}$ & 8.76 & 20.65 & -- & -- & -- \\
$\mathbf{0 . 5}$ & $\mathbf{0 . 7}$ & 14.14 & 31.67 & 14.61 & 10.23 & 7.56 \\
$\mathbf{1 . 0}$ & $\mathbf{1 . 0}$ & 23.58 & 47.37 & 23.79 & 17.23 & 12.56 \\
$\mathbf{1 . 5}$ & $\mathbf{1 . 2}$ & 30.93 & 58.13 & 31.67 & 22.02 & 16.44 \\
$\mathbf{2}$ & $\mathbf{1 . 4}$ & 38.38 & 66.05 & 38.81 & 27.30 & 19.33 \\
$\mathbf{3}$ & $\mathbf{1 . 7}$ & 48.95 & 75.19 & 50.89 & 35.78 & 24.53 \\
$\mathbf{4}$ & $\mathbf{2 . 0}$ & 58.11 & 81.43 & 59.71 & 43.79 & 29.41 \\
$\mathbf{5}$ & $\mathbf{2 . 2}$ & 65.00 & 85.13 & 66.88 & 51.76 & 35.01 \\
$\mathbf{6}$ & $\mathbf{2 . 4}$ & 69.50 & 86.80 & 72.79 & 58.62 & 40.86 \\
\hline
\end{tabular}

*Mean $(\mathrm{n}=6)$ 
was confirmed by the correlation coefficients ( $r$ ) shown in Table II (all above 0.99), ensuring that the release rate was constant within these time intervals, for all samples. Thus, the kinetics of Higuchi could, in fact, be applied (linear plot of amount released versus $\sqrt{t}$ ).

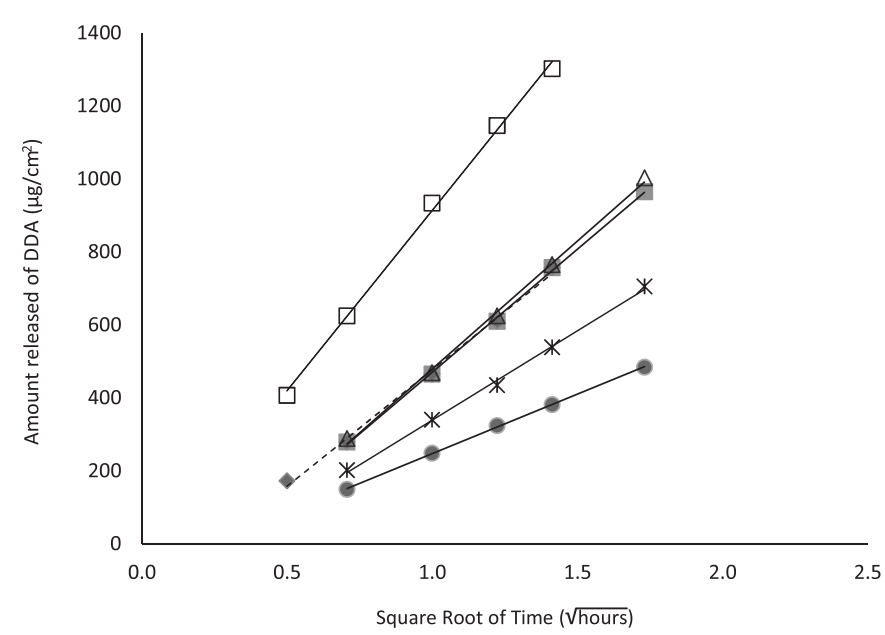

FIGURE 3 - In vitro release of DDA as a function of $\sqrt{t}$, using the data points selected, employing the polyethersulfone membrane $(n=6)$.

TABLE II - Release rate, correlation coefficient and lag time of products using a polyethersulfone membrane.

\begin{tabular}{lccc}
\hline Manufacturer & $\begin{array}{c}\text { Release rate } \\
\left(\boldsymbol{\mu g} / \mathbf{c m}^{2} / \sqrt{\mathbf{h}}\right)^{\diamond}\end{array}$ & $\begin{array}{c}\text { Correlation } \\
\text { coefficient }(\mathbf{r})\end{array}$ & $\begin{array}{c}\text { Lag time } \\
(\text { minutes })\end{array}$ \\
\hline Reference* $^{*}$ & $674.18 \pm 53.53$ & 0.9995 & 5.53 \\
Reference** $^{* *}$ & $637.57 \pm 42.72$ & 0.9981 & 3.85 \\
Generic A** $^{*}$ & $987.52 \pm 25.75$ & 0.9990 & 0.34 \\
Generic B* $^{*}$ & $700.27 \pm 32.52$ & 0.9990 & 6.01 \\
Generic C* $^{*}$ & $489.49 \pm 12.76$ & 0.9988 & 5.74 \\
Generic D* & $325.76 \pm 13.37$ & 0.9998 & 3.53 \\
\hline
\end{tabular}

${ }^{\circ}$ Mean $\pm \mathrm{SD}(\mathrm{n}=6),{ }^{*}$ Calculated using the data points within 0.5 to $3 \mathrm{~h},{ }^{* *}$ Calculated using the data points within 0.25 to $2 \mathrm{~h}$

The lag time is defined as the time required for a system involving the passage of a substance through a membrane to reach equilibrium (Aulton. 2005). The lag time is calculated by extrapolating the linear regression line along the time axis. An intercept of " $x$ " which generally corresponds to a small fraction of an hour is a normal characteristic in release assays plots (FDA. 1997). The values in Table II show that the products had a short lag time, that is, the diffusion equilibrium of the process was established within a short period of time. Therefore, the polyethersulfone membrane did not act as a barrier to the DDA diffusion.

\section{Comparison of in vitro release rate}

The release results can reflect the combined effect of several physical and chemical parameters, including the solubility, particle size and rheological properties of the dosage form. This explains the differences between the formulations evidenced in every test performed individually and this is considered as a test to be used for the "final quality control" (FDA, 1997).

The formulations of the products analyzed in this study had different characteristics, with qualitative and possibly quantitative differences in the excipients (Table III) and method of preparation (unknown).

Only generic B was considered to be similar to the reference drug product according to the statistical method used (Table IV). Generic B had a similar profile to the reference product, and the qualitative composition of the formulation was also found to be closest to Cataflam Emulgel ${ }^{\circledR}$, with the same excipients.

Generic $\mathrm{C}$ had a slower release rate than the reference. The presence of a consistency agent/coemulsifying cetostearyl alcohol may have contributed to the lower flux.

Generic D was the generic sample with the lowest flux. This was the only sample for which the type of surfactant employed was not specified (only given as a non-ionic emulsifying wax) and no emollient was separately mentioned.

Generic A presented the fastest release rate and different excipients, polyacrylamide being used as the gel forming polymer rather than $\mathrm{Carbopol}^{\circledR}$, which was the excipient in the other samples. The emulsifier (lanolin alcohol) also differed from that used in the other samples tested and this was the only product that did not contain isopropyl alcohol as a solubilizer. This may lead to a lower solubility of the vehicle, as the thermodynamic activity of the DDA may be higher, thus increasing the partition coefficient obtained in the receptor medium. These qualitative differences may have facilitated the DDA diffusion.

Bemvindo (2006) studied miconazole nitrate cream formulations available on the Brazilian market and also noted differences in the drug release of the products according to the qualitative differences of the formulations. Bemvindo reported that the excipient propylene glycol present in some formulations increased the solubility of miconazole, affecting the thermodynamic activity and decreasing the drug partition coefficient of the receptor medium.

The in vitro release test alone is not a substitute for the assessment of the bioavailability or in vivo 
TABLE III - Comparison of diclofenac diethylamine gel formulations

\begin{tabular}{|c|c|c|c|c|c|}
\hline \multirow[b]{2}{*}{ Function } & \multicolumn{5}{|c|}{$\begin{array}{c}\text { Ingredients } \\
\text { (Provided on manufacturer's label) }\end{array}$} \\
\hline & $\begin{array}{l}\text { Cataflam Emulgel }^{\circledR} \\
\text { (Reference) }\end{array}$ & Generic A & Generic B & Generic C & Generic D \\
\hline $\begin{array}{l}\text { Gel-forming } \\
\text { polymer }\end{array}$ & Carbopol $^{\circledR}$ & Polyacrylamide & Carbopol $^{\circledR} 934$ & Carbopol $^{\circledR} 940$ & Carbopol $^{\circledR}$ \\
\hline Emulsifier & Cetomacrogol 1000* & Lanolin alcohol & $\begin{array}{l}\text { Polyoxyl cetostearyl } \\
\text { ether }\end{array}$ & $\begin{array}{c}\text { Polyoxyl } 20 \\
\text { cetostearyl ether }\end{array}$ & $\begin{array}{c}\text { Non-ionic } \\
\text { emulsifying wax }\end{array}$ \\
\hline Solvent & Isopropyl alcohol & - & Isopropyl alcohol & Isopropyl alcohol & Isopropyl alcohol \\
\hline Humectant & Propylene glycol & Propylene glycol & Propylene glycol & Propylene glycol & Propylene glycol \\
\hline $\begin{array}{l}\text { Lipophilic vehicle/ } \\
\text { Emollient }\end{array}$ & $\begin{array}{l}\text { Liquid paraffin }{ }^{\diamond} \\
\text { Coco-caprylate/ } \\
\text { caprate }\end{array}$ & $\begin{array}{l}\text { Isoparaffin, } \\
\text { Mineral oil }{ }^{\diamond} \\
\text { Lauryl alcohol }\end{array}$ & $\begin{array}{l}\text { Liquid petrolatum } \\
\text { Decyl oleate }\end{array}$ & Liquid vaseline $^{\diamond}$ & - \\
\hline $\begin{array}{l}\text { Viscosity-increasing } \\
\text { agent /Co-emulsifier }\end{array}$ & - & - & - & Cetostearyl alcohol & - \\
\hline Preservative & - & $\begin{array}{l}\text { Methyl, Propyl, } \\
\text { Butyl and Ethyl } \\
\text { paraben, } \\
\text { 2-phenoxyethanol }\end{array}$ & - & $\begin{array}{l}\text { Methyl and } \\
\text { Propyl paraben }\end{array}$ & $\begin{array}{l}\text { Methyl and } \\
\text { Propyl paraben }\end{array}$ \\
\hline Alkalizing agent & Diethylamine & - & Diethylamine & Sodium Hydroxide & Sodium Hydroxide \\
\hline Other & Perfume & EDTA & $\begin{array}{l}\text { BHT, Melody } \\
\text { essence }\end{array}$ & Fragrance & Pentalys essence \\
\hline
\end{tabular}

* Cetomacrogol 1000 is the commercial name for the polyoxyl cetostearyl ether, ${ }^{\circ}$ Synonyms

Note: Water and DDA are not present in the table but are constituents mentioned by all manufacturers.

bioequivalence of dermatologic formulations produced by different manufacturers (FDA, 1997). This is because a greater amount of drug release from the formulation in in vitro experiments is not a guarantee of increased availability of the drug at the site of action, since the skin penetration of drugs involves many factors. The penetration characteristics of each formulation (e.g. the presence of permeation enhancers) will control the amount of drug present in each layer of skin (Bemvindo, 2006).

Many different absorption promoters are used for various reasons in topical and transdermal preparations. For example, a topical formulation may contain propylene glycol as the vehicle, a surfactant to solubilize the drug and a terpene as a perfume. These formulations can penetrate skin to a greater degree due to the presence of these agents, although they are not used specifically for this purpose (Williams, Barry, 2004).

Although the release test results are only indicative of the formulation performance, the flux values obtained in these tests allow the following conclusions to be drawn: the vehicle used in the generic A sample enabled greater release of DDA to the receptor medium used, when compared to the reference drug product. If the same behavior occurs in vivo, it can be deduced that a higher

TABLE IV - Statistical testing of difference between reference and generic samples (data collected using polyethersulfone membrane)

\begin{tabular}{lcc}
\hline Comparison & $\begin{array}{c}\text { Limit values of the } \mathbf{9 0 \%} \\
\text { confidence interval }\end{array}$ & Conclusion* \\
\hline Reference x Generic A & $146.60-165.94$ & NOT SIMILAR \\
Reference x Generic B & $94.99-111.93$ & SIMILAR \\
Reference x Generic C & $66.82-77.74$ & NOT SIMILAR \\
Reference x Generic D & $45.17-52.14$ & NOT SIMILAR \\
\hline
\end{tabular}

*Requirement for similarity: values must be between $75 \%$ and $133.33 \%$ (FDA, 1997) 
TABLE V - Release rate, correlation coefficient and lag time of products using a cellulose acetate membrane.

\begin{tabular}{lccc}
\hline Manufacturer & Release rate $\left(\boldsymbol{\mu g} / \mathbf{c m}^{2} / \sqrt{\mathbf{h}}\right)^{\diamond}$ & Correlation coefficient $(\mathbf{r})$ & Lag time $(\mathbf{m i n u t e s})$ \\
\hline Reference* & $731.63 \pm 35.91$ & 0.9992 & 6.26 \\
Reference** & $682.28 \pm 34.37$ & 0.9986 & 4.25 \\
Generic A** & $1.032 .33 \pm 48.76$ & 0.9988 & 0.67 \\
Generic B* & $676.82 \pm 7.85$ & 0.9995 & 5.63 \\
Generic C* & $478.50 \pm 24.44$ & 0.9993 & 5.14 \\
Generic D* & $326.33 \pm 9.32$ & 0.9997 & 4.16 \\
\hline
\end{tabular}

${ }^{8}$ Mean $\pm \mathrm{SD}(\mathrm{n}=6) .{ }^{*}$ Calculated using the data points within 0.5 to $3 \mathrm{~h} ;{ }^{* *}$ Calculated using the data points within 0.25 to $2 \mathrm{~h}$

amount of DDA will be available to penetrate the skin within a shorter time. For the generic $\mathrm{C}$ and $\mathrm{D}$ samples, the DDA probably had greater affinity for the vehicle resulting in a lower amount being released in comparison with the reference.

This may affect the performance of these samples because when drugs are applied topically a pharmacologically active agent must be released from its vehicle before it can come into contact with the epidermal surface and be available for skin penetration (Guy, 1986).

\section{Comparison of the results obtained with polyethersulfone and cellulose acetate membranes}

The in vitro drug release profiles for the DDA release from the products tested, using a cellulose acetate membrane, are given in Figure 4. The good linearity observed for the selected data points was confirmed by the correlation coefficients (r) shown in Table V (all above 0.99), verifying that the release rate was constant during

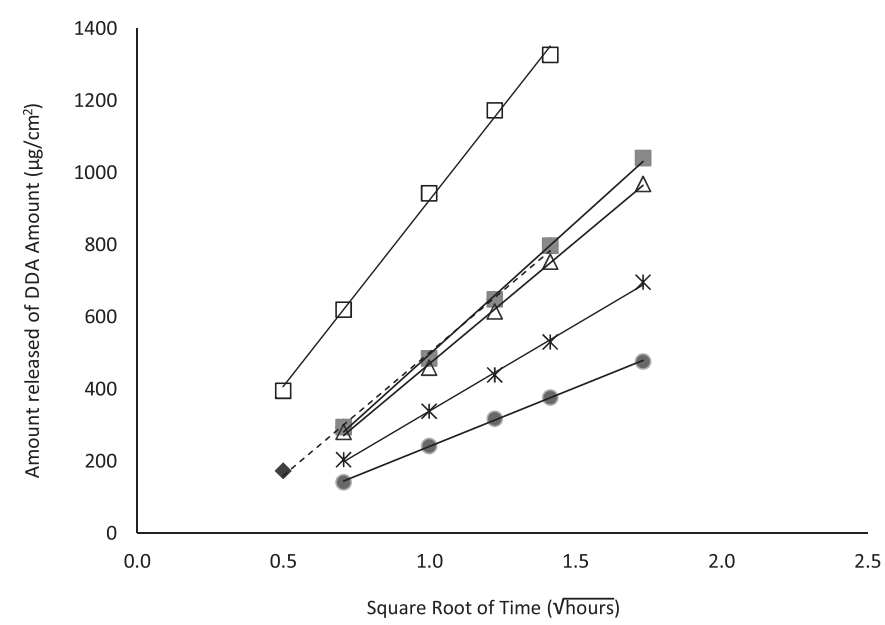

FIGURE 4 - In vitro release of DDA as a function of $\sqrt{t}$, using the selected data points (data collected employing a cellulose acetate membrane and $n=6$ ). the whole test period, for all samples. To statistically analyze the flux values obtained with the membranes the paired t-test was performed. As can be seen in Table VI, no differences were observed between the cellulose acetate and polyethersulfone membranes in terms of the flux values obtained for the five products (significance level of 5\%).

TABLE VI - Statistical test: polyethersulfone membrane $\mathrm{x}$ cellulose acetate membrane

\begin{tabular}{lll}
\hline $\begin{array}{l}\text { Polyethersulfone } \\
\text { membrane x Cellulose } \\
\text { acetate membrane }\end{array}$ & $\boldsymbol{p}$ value & Conclusion* \\
\hline Reference & 0.1200 & SIMILAR \\
Generic A & 0.0569 & SIMILAR \\
Generic B & 0.1893 & SIMILAR \\
Generic C & 0.2099 & SIMILAR \\
Generic D & 0.9108 & SIMILAR \\
\hline
\end{tabular}

$*(p<0.05)$

One of the most critical steps in the development of an in vitro release method is the selection of the synthetic membrane, which must provide an inert support for the formulation (Corbo et al., 1993). According to published data (Shah et al., 1989; Shah, Elkins, 1995; Shah, Elkins, Williamns et al., 1999; $\mathrm{Ng}$ et al., 2010) there is no standard for the membrane, which should thus be tested for each drug, vehicle and receptor medium. The most common membranes employed in in vitro release test are silicone, cellulose and polysulfone membranes ( $\mathrm{Ng}$ et al., 2010).

The cellulose acetate and polyethersulfone membranes used in this study were both hydrophilic and showed similar fluxes, porosity and thickness. DDA, an amphiphilic drug (Kriwet, Mueller-Goyman, 1995; Djordjevic, Primorac, Stupar, 2005), is compatible with hydrophilic membranes. A similar result obtained in a comparison between cellulose acetate and polysulfone membranes was reported by Bemvindo (2006), where the 
author found no difference between the two membranes in tests with miconazole nitrate cream.

These studies are important for characterizing the performance of each drug class according to the release test specificities, such as the selection of the membrane.

\section{CONCLUSIONS}

The results reported herein indicate that the drug release rates for the drug products analyzed were not influenced by the type of synthetic membrane used (polyethersulfone or cellulose acetate).

Only the generic B sample was considered to be similar to the reference drug product, for which the formulation was qualitatively most similar to the reference. The difference between the fluxes of the products may be attributed to different vehicle components. Thus, different formulations may result in distinct amounts of drug penetration into the skin and may, thus, exhibit different intensities of activity (Shah et al., 1991). This results obtained highlight the influence of excipients on the performance of topical products. However, in vitro release tests only provide an indication of the formulation performance.

The requirement of the use of this tool, if imposed in the future by Brazilian legislation to ensure the equivalence of semisolid dosage forms, should be accompanied by more stringent criteria regarding the qualitative and quantitative excipient composition of generic candidates.

\section{REFERENCES}

AULTON, M.E. Delineamento de formas farmacêuticas. 2nd ed. Porto Alegre: Artmed, 2005. 677 p.

BEMVINDO, C.S. Estudo comparativo da liberação e penetração cutânea de nitrato de miconazol de emulsões tópicas comerciais. Rio de Janeiro, 2006. 110 p. [Master's Degree Thesis, Federal University of Rio de Janeiro, Brazil].

BRASIL. Resolução n.897, de 29 de Maio de 2003. Determina a publicação do "Guia para Isenção e Substituição de Estudos de Bioequivalência”. Agencia Nacional de Vigilância Sanitária, Brasília, June 02, 2003. Section 1, p.54.

BRASIL. Resolução RDC n. 48, de 6 de Outubro de 2009. Dispõe sobre realização de alteração, inclusão, suspensão, reativação, e cancelamento pós-registro de medicamentos e dá outras providências. Agencia Nacional de Vigilância Sanitária, Brasília, October 07 2009. Section 1, p.60-67.
BRITISH PHARMACOPOEIA. London: The Stationery Office, 2008. v.3, p.2507-2508.

CORBO, M.; SCHULTZ, T.W.; WONG, G.K.; VAN BUSKIRK, A. Development and Validation of in vitro release testing methods for semisolid formulations. Pharm. Technol., v.19, n.9, p.112-128, 1993.

DJORDJEVIC, L.; PRIMORAC, M.; STUPAR, M. In vitro release of diclofenac diethylamine from caprylocaproyl macrogolglycerides based microemulsions. Int. J. Pharm., v.296, n.1, p.73-79, 2005.

FOOD AND DRUG ASMINISTRATION (FDA). Guidance for industry: SUPAC-SS nonsterile semisolid dosage forms, scale-up and post-approval changes, chemistry, manufacturing, and controls, in vitro Release testing and in vivo bioequivalence documentation. Rockville: Center of Drug Evaluation and Research, 1997. 26 p.

GUY, R.H.; GUY, A.H.; MAIBACH, H.I.; SHAH, V.P. The bioavailability of dermatological and other topically administered drugs. Pharm. Res., v.3, n.5, p.253-262, 1986.

GUY, R.H.; HADGRAFT, J. On the determination of drug release rates from topical dosage forms. Int. J. Pharm., v.60, n.2, p.R1-R3, 1990.

HIGUCHI, W.I. Analysis of data on the medicament release from ointments. J. Pharm. Sci., v.51, n.8, p.802-804, 1962.

KRIWET, K.; MUELLER-GOYMANN, C.C. Diclofenac release from phospholipid drug systems and permeation through excised human stratum corneum. Int. J. Pharm., v.125, n.2, p.231-242, 1995.

NG, S.F.; ROUSE, J.; SANDERSON, D.; ECCLESTON, G. A comparative study of transmembrane diffusion and permeation of ibuprofen across synthetic membranes using franz diffusion cells. Pharmaceutics, v.2, n.2, p.209-223, 2010.

SHAH, V.P.; ELKINS, J.S.; LAM, S.Y.; SKELLY, J.P. Determination of in vitro drug release from hydrocortisone creams. Int. J. Pharm., v.53, n.1, p.53-59, 1989.

SHAH, V.P.; ELKINS, J.S.; HANUS, J.; NOORIZADEH, C.; SKELLY, J.P. In vitro release of hydrocortisone from topical preparations and automated procedure. Pharm. Res., v.8, n.1, p.55-59, 1991 
SHAH, V.P.; ELKINS, J.S. In-vitro release from corticosteroid ointments. J. Pharm. Sci., v.84, n.9, p.1139-1140, 1995.

SHAH, V.P.; ELKINS, J.S.; WILLIAMS, R.L. Evaluation of the test system used for in vitro release of drugs for topical dermatological drug products. Pharm. Dev. Technol., v.4, n.3, p.377-385, 1999.

SHAH, V.P.; ELKINS, J.S.; SHAW, S.; HANSON, R. In vitro release: Comparative evaluation of vertical diffusion cell system and automated procedure. Pharm. Dev. Technol., v.8, n.1, p.97-102, 2003.

SHAH, V.P. In vitro release from semisolid dosage forms. In: BRONAUGH R.L.; MAIBACH, H.I.(Eds.) Percutaneous absorption. Boca Raton: Taylor \& Francis Group, 2005. p.473-480.

SILVA, J.A.; SANTANA, D.P.; BEDOR, D.G.C.; BORBA, V.F.C.; LIRA, A.A.M.; EGITO, E.S.T. Estudo de liberação e permeação in vitro do diclofenaco dietilamônio em microemulsão gel-like. Quím. Nova, v.32, n.6, p.13891393, 2009.

TOSCANO, C.; CAMPOS, R.; BICA, A.; FARINHA, A.R. Sensibilidade dos ensaios de difusão in vitro na detecção de alterações induzidas pelo efeito da temperatura em formulações semi-sólidas de cetoconazol. Rev. Port. Farm., v.67, n.4, p.105-115, 1997.
TOSCANO, C.; CAMPOS, R.; BICA, A.; FARINHA, A.R. Desenvolvimento e validação de um sistema de avaliação da liberação in vitro do peróxido de benzoíla veiculado em géis. Rev. Bras. Cienc. Farm., v.37, n.3, p.341-346, 2001.

UEDA, C.T.; SHAH, V.P.; DERDZINSKI, K.; EWING, G.; FLYNN, G.; MAIBACH, H.; MARQUES, M.; RYTTING, H.; SHAW, S.; THAKKER, K.; YACOBI, A. Topical and transdermal drug products. Pharm. Forum, v.35, n.3, p.750-764, 2009.

WILLIAMS, A.C.; BARRY, B.W. Penetration enhancers. Adv. Drug. Deliv. Rev., v.56, n.5, p.603-618, 2004.

ZATZ, J.L.; SEGERS, J.D. Techniques for measuring in vitro release from semisolids. Dissolution Technol., v.5, n.1, p.3-13, 1998.

Received for publication on $16^{\text {th }}$ October 2012 Accepted for publication on $07^{\text {th }}$ Mach 2013 
